\title{
KAJIAN KRITIS PENGGUNAAN APLIKASI TELE-CONFERENCE ZOOM DALAM PERKULIAHAN ONLINE SELAMA MASA TANGGAP COVID-19
}

\section{Aulia Nur Rasyid ${ }^{1}$, Syarifatul Amaliyah ${ }^{2}$, Amaliya Islami Nurlaili ${ }^{3}$}

${ }^{123}$ Program Studi Tadris IPA FTIK Institut Agama Islam Negeri Jember, Indonesia

Corresponding Author: rasyidaulia20@iainjember.ac.id

\begin{abstract}
Abstrak. Pembelajaran daring merupakan cara yang dapat dilakukan oleh instansi pendidikan pada masa pandemi COVID-19. Pembelajaran daring telah mengubah wajah pendidikan di Indonesia yang semula pembelajaran secara offline atau pembelajaran tatap muka langsung menjadi online. Banyak aplikasi yang dapat digunakan untuk memudahkan pembelajaran, seperti aplikasi teleconference zoom yang marak dipakai oleh para dosen dan mahasiswa. Teleconference Zoom merupakan Platfrom Cloud yang menawarkan visual secara video dan audio conferencing, chat, dan webinar. Penulisan ini bertujuan untuk mendeskripsikan reaksi mahasiswa dalam menanggapi pembelajaran jarak jauh (PJJ) melalui Aplikasi Zoom. Metode yang digunakan dalam penulisan ini menggunakan pendekatan fenomenologis. Kepenulisan artikel ini merujuk pada Hasil observasi yang menggambarkan fenomena pembelajaran aktif dengan menggunakan Zoom dalam perspektif mahasiswa selama masa tanggap COVID-19. Oleh karena itu, aplikasi teleconference zoom sangat disarankan bagi pengajar untuk memaksimalkan pembelajaran jarak jauh.
\end{abstract}

Kata Kunci: Analisis kritis, Teleconference, Zoom Cloud

\begin{abstract}
Online learning is the only way that educational institutions can do during the COVID-19 pandemic. Online learning has changed the face of education in Indonesia, which was originally offline learning or face-to-face learning or blended, to fully online. Many applications can be used to facilitate learning, such as the zoom teleconference application which is widely used by lecturers and students. Zoom is a Cloud Platform that offers visual video and audio conferencing, chat and webinars. This writing aims to describe student reactions in response to distance learning (PJJ) through the Zoom application. The method used in this paper uses a phenomenological approach. The authorship of this article refers to the results of observations that describe the phenomenon of active learning using Zoom in the perspective of students during the COVID-19 response period. Therefore, the teleconference zoom application the most recommended for teachers to maximize distance learning.
\end{abstract}

Keywords: Critical Analysis, Online Learning, Zoom Teleconference.

\section{PENDAHULUAN}

Pandemi virus COVID-19 yang tengah mewabah membuat seluruh sektor pemerintah termasuk sistem pembelajaran makro dan mikro mulai bertransformasi. Sistem pendidikan selama masa tanggap ini mengalami perubahan di seluruh negara termasuk di tanah air kita. Upaya peningkatan mutu pendidikan di indonesia selalu menjadi isu penting dalam penyelenggaraan Sistem Pendidikan Nasional. Peningkatan kualitas media pendidikan ini menjadi salah satu strategi pokok selain pemerataan kesempatan dan akses pendidikan serta peningkatan relevansi dan efisiensi. 
Reformasi holistik di dalam proses pembelajaran yang telah beralih pada pembelajaran aktif berbasis teori konstrutivisme yang ditawarkan oleh Vgotsky dan Jean Piaget. Teori ini menyuguhkan berbagai proses pedagogis yang lebih mengandalkan pada perluasan dan pengayaan sumber belajar untuk memfasilitasi kegiatan belajar siswa, karena menurut teori kontruktivisme, pendidik harus memberi kesempatan pada para peserta didik untuk melakukan eksplorasi dan elaborasi. kemudian guru juga memberikan konfirmasi pada pendidik sebagai senior dalam pembelajaran yang lebih berpengalaman dalam eksplorasi terhadap bahan-bahan yang mereka pelajari (Ali, 2009).

Oleh karena itu, seluruh sivitas akademika dituntut agar menguasai seluruh media, dalam rangka mengembangkan media pembelajaran jarak jauh (PJJ) sebagai bentuk upaya penerapan aturan social distancing yang telah dikemukakan oleh pemerintah (Mona, 2020). Berdasarkan Undang-Undang Perguruan Tinggi nomer 12. tahun 2012, pasal 31 tentang Pendidikan Jarak Jauh (PJJ) menjelaskan bahwa PJJ merupakan proses belajar mengajar yang dilakukan secara jarak jauh melalui penggunaan berbagai media komunikasi (Fitria dkk., 2016). Melalui undang-undang tersebut, kementerian Pendidikan dan Kebudayaan serta Kementerian Agama Republik Indonesia menjadikan landasan diperbolehkannya kuliah jarak jauh. Ditambah lagi hasil keputusan dari menteri pendidikan bahwa kegiatan pembelajaran di seluruh instansi pendidikan baik sekolah dan perguruan tinggi dilakukan di rumah masing-masing melalui aplikasi interaktif yang telah tersedia.

Menteri pendidikan mengeluarkan Surat Edaran Nomor 3 tahun 2020 tentang Pencegahan Penyebaran wabah virus COVID-19 Pada Satuan Pendidikan yang menyatakan bahwa mengistirahatkan kegiatan di dalam sekolah dan perguruan tinggi. Keharusan ini dijalankan secara distributif melalui work from home dan learning from home. (Surat Edaran Pencegahan COVID-19 Pada Satuan Pendidikan, 2020) Peralihan Pembelajaran ke dalam sistem daring ini berdampak di lingkungan IAIN Jember sebagai PTKIN yang berada di bawah naungan Kementerian Agama.

Dengan bergantinya sistem pembelajaran konvensional ke pembelajaran modern, Pastinya menyimpan banyak kontroversi di kalangan warga kampus tak terkecuali di lingkungan IAIN Jember. Dalam masalah ini, penulis melihat banyak mahasiswa IAIN Jember kesulitan dalam menggunakan media pembelajaran yang dapat membantu perkuliahan mereka. Media pembelajaran tersebut berbentuk aplikasi daring. Oleh karenanya, dibutuhkan berbagai indikator sebagai acuan kelayakan penerapan media pembelajaran. Indikator tersebut meliputi aspek; 1) Technical Quality; 2) Usability; 3) Elemen Media Visual; . Dari aspek tersebut penulis dapat menanggapi kelayakan suatu media pembelajaran, termasuk ketidaknyamanan pembelajaran. (Crozat dkk., 1999) Fenomena ketidaknyamanan tersebut di dalam proses pembelajaran membuat para mahasiswa sulit memahami materi. Bentuk fenomena miskonsepsi materi ini, apabila ditinjau pada aspek usability yaitu, kesulitan dalam mengoperasikan aplikasi/software pada perangkat mereka. Sedangkan pada aspek technical quality yaitu, pada beberapa perangkat keras pengguna tidak dapat mengoperasikan aplikasi dikarenakan ketidakmampuan perangkat keras untuk memasang aplikasi. (Karolcík dkk., 2015)

Media pembelajaran pun menjadi bahan utama yang harus dikuasi oleh para pengajar dan pelajar. Karena perkembangan media pembelajaran mengikuti arus perkembangan teknologi dari zaman yang paling tua. Pada era perkembangan media cetak proses belajar masih dalam bentuk teknologi cetak atas dasar prinsip mekanik, seperti koran, majalah dan buku. Kemudian bergantinya zaman, muncul teknologi yang lebih kontemporer dengan menggunakan teknologi mikroprosesor yang melahirkan pemakaian komputer dan kegiatan interaktif dan aktif. (AR, 2018)

Menurut Arsyad, pengertian ringkas mengenai media kontemporer antara lain ialah; 1)Telekonferensi adalah suatu teknik percakapan dalam bentuk kelompok besar maupun kecil dengan menggunakan mikrofon dan amplifier khusus serta dihubungkan satu dengan lainnya sehingga menciptakan suasana diskusi tanpa memandang letak geografis; 2) Kuliah Jarak Jauh (tele-lecture) adalah suatu teknik penyampaian ilmu oleh seorang ahli dalam suatu bidang ilmu tertentu kepada audiens melalui amplifier telepon. Pendengar dapat bertanya kepada pembicara dan kelompok itu dapat mendengarkan 
jawaban/tanggapan pembicara; 3) Computer-assisted instruction adalah suatu sistem penyampaian materi pelajaran yang berbasis mikroprosesor yang pelajarannya dirancang dan diprogram ke dalam sistem tersebut (Arsyad, 2011).

Menurut Oemar Hamalik media pembelajaran adalah alat, metode, dan teknik yang digunakan dalam rangka lebih mengefektifkan komunikasi dan interaksi antara guru dan siswa dalam proses pendidikan dan pengajaran di sekolah (MARDININGRUM, 2020). Salah satu media pembelajaran teleconference yang banyak digunakan dalam perkuliahan di IAIN Jember adalah Zoom Meet Clouds. Zoom Meet merupakan platfrom tele-conferance yang memaparkan dosen dan mahasiswa dapat bertatap muka selayaknya melakukan permbelajaran langsung (Kusuma \& Hamidah, 2020).

Berbagai fitur yang ditawarkan di dalam aplikasi zoom dapat membantu dalam proses perkuliahan jarak jauh, tetapi keluhan yang datang karena borosnya kuota selama pemakaian platfrom ini pun tak sedikit. Oleh karena itu, penulis mengangkat artikel ini sebagai bentuk manifestasi kajian kritis mengenai penggunaan teleconferance zoom selama masa tanggap darurat COVID-19 dalam perkuliahan online.

\section{METODE}

Pada metode penelitian ini menjelaskan tentang: 1) Jenis penelitian; 2) Metode Pengumpulan Data; 3) Metode Analisis Data. Untuk lebih jelasnya akan diuraikan sebagai berikut.

\section{1) Jenis Penelitian}

Jenis penelitian ini menggunakan pendekatan deskriptif kualitatif dengan menekankan bentuk desain penelitian Fenomenologi. Jenis penelitian fenomenologi merupakan teknik penelitian dengan meninjau fenomena esensial partisipan dalam pengalaman hidup penulis terhadap lingkungan di sekitar penulis, dengan cara mengumpulkan data observasi partisipan. (Morse, 2015) Penelitian ini berguna untuk mengetahui, menjelaskan, dan memperkirakan kejadian-kejadian sains dan sosial yang akan terjadi dan sedang terjadi di era modern ini, misalnya penelitian yang dilaksanakan sebagai bentuk upaya apresiasi suara mahasiswa terhadap perkuliahan akibat wabah virus COVID-19.

\section{2) Metode Pengumpulan Data}

Artikel ini menggunakan metode telaah pustaka, observasi, wawancara dan Focus Grup Discussion (FGD). Metode studi literasi adalah kajian pustaka berdasarkan pembahasan suatu teori yang bertolak dari asumsi pengetahuan yang bersifat subjektif kemudian ditulis oleh ahli di dalam berbagai sumber informasi. Sumber informasi yang kami dapatkan berupa buku, jurnal dan website ilmiah. Selain itu, penulis juga mendapatkan data melalui pengumpulan informasi berupa pertanyaan-pertanyaan sebagai bentuk pengambilan jawaban observasi. Observasi ini merupakan peninjauan secara cermat. Selain itu, observasi ini memerlukan waktu yang singkat untuk menjawab pertanyaan. Selanjutnya penulis juga melakukan wawancara yang berisi pertanyaan-pertanyaan subjektif guna mendapatkan keterangan dan pendapat mengenai suatu peristiwa secara faktual kemudian membandingkan dengan data sekunder dari literatur. FGD adalah suatu kegiatan diskusi kelompok yang diadakan untuk kepentingan khusus guna mendiskusikan suatu masalah melalui asumsi-asumsi yang tengah beredar (brain storming). FGD dilaksanakan oleh penulis dan dosen ahli.

\section{3) Metode Analisis Data}

Analisis data dilakukan sebagai suatu proses pengelompokan data yang selalu didasarkan pada tujuan yang ingin dicapai pada artikel ini. Metode analisis data pada artikel ini dilaksanakan secara deskriptif. Analisis data secara deskriptif bertujuan untuk menjelaskan atau mendeskripsikan suatu keadaan, peristiwa, atau suatu

A. N. Rasyid,dkk.: Kajian Kritis Penggunaan Aplikasi Tele-Conference Dalam Perkuliahan Online Selama Masa Tanggap Covid-19| 91 
objek. Menurut Miles \& Huberman, analisis terdiri dari tiga alur kegiatan yang terjadi secara bersamaan yaitu: reduksi data, penyajian data, penarikan kesimpulan/verifikasi. (Miles \& Huberman, 1994) Mengenai ketiga alur tersebut secara lebih lengkapnya adalah sebagai berikut:

\section{Reduksi Data}

Reduksi data diartikan sebagai proses pemilihan, pemusatan perhatian pada penyederhanaan, pengaburan, dan transformasi data kasar yang muncul dari catatan-catatan tertulis di lapangan. Reduksi data berlangsung terus-menerus selama proyek yang berorientasi penelitian kualitatif berlangsung. Antisipasi akan adanya reduksi data sudah tampak waktu penelitiannya memutuskan (sering kali tanpa disadari sepenuhnya) kerangka konseptual wilayah penelitian, permasalahan penelitian, dan pendekatan pengumpulan data mana yang dipilihnya. (Gunawan, 2013) Selama pengumpulan data berlangsung, terjadilan tahapan reduksi selanjutnya (membuat ringkasan, mengkode, menelusur tema, membuat gugus-gugus, membuat partisi, membuat memo). Reduksi data/transformasi ini berlanjut terus sesudah penelian lapangan, sampai laporan akhir lengkap tersusun.

Reduksi data merupakan suatu bentuk analisis yang menajamkan, menggolongkan, mengarahkan, membuang yang tidak perlu, dan mengorganisasi data dengan cara sedemikian rupa hingga kesimpulan-kesimpulan akhir dapat ditarik dan diverifikasi. Dengan reduksi data peneliti tidak perlu mengartikannya sebagai kuantifikasi. Data kualitatif dapat disederhanakan dan ditransformasikan dalam aneka macam cara, yakni: melalui seleksi yang ketat, melalui ringkasan atau uraian singkat, menggolongkannya dalam satu pola yang lebih luas, dan sebagainya. Kadangkala dapat juga mengubah data ke dalam angka-angka atau peringkat-peringkat, tetapi tindakan ini tidak selalu bijaksana.

\section{Penyajian Data}

Miles \& Huberman membatasi suatu penyajian sebagai sekumpulan informasi tersusun yang memberi kemungkinan adanya penarikan kesimpulan dan pengambilan tindakan. Mereka meyakini bahwa penyajian-penyajian yang lebih baik merupakan suatu cara yang utama bagi analisis kualitatif yang valid, yang meliputi: berbagai jenis matrik, grafik, jaringan dan bagan. Semuanya dirancang guna menggabungkan informasi yang tersusun dalam suatu bentuk yang padu dan mudah diraih. Dengan demikian seorang penganalisis dapat melihat apa yang sedang terjadi, dan menentukan apakah menarik kesimpulan yang benar ataukah terus melangkah melakukan analisis yang menurut saran yang dikisahkan oleh penyajian sebagai sesuatu yang mungkin berguna.

\section{Menarik Kesimpulan}

Penarikan kesimpulan menurut Miles \& Huberman hanyalah sebagian dari satu kegiatan dari konfigurasi yang utuh. Kesimpulan-kesimpulan juga diverifikasi selama penelitian berlangsung. Verifikasi itu mungkin sesingkat pemikiran kembali yang melintas dalam pikiran penganalisis (peneliti) selama ia menulis, suatu tinjauan ulang pada catatan-catatan lapangan, atau mungkin menjadi begitu seksama dan menghabiskan tenaga dengan peninjauan kembali serta tukar pikiran di antara teman sejawat untuk mengembangkan kesepakatan intersubjektif atau juga upaya-upaya yang luas untuk menempatkan salinan suatu temuan dalam seperangkat data yang lain. (Rusdiantoro, 2020) Singkatnya, makna-makna yang muncul dari data yang lain harus diuji kebenarannya dan kecocokannya, yakni yang merupakan validitasnya. Kesimpulan akhir tidak hanya terjadi pada waktu proses pengumpulan data saja, akan tetapi perlu diverifikasi agar benar-benar dapat dipertanggungjawabkan. Secara skematis proses analisis data menggunakan model analisis data interaktif Miles dan Huberman dapat dilihat pada bagan berikut: 


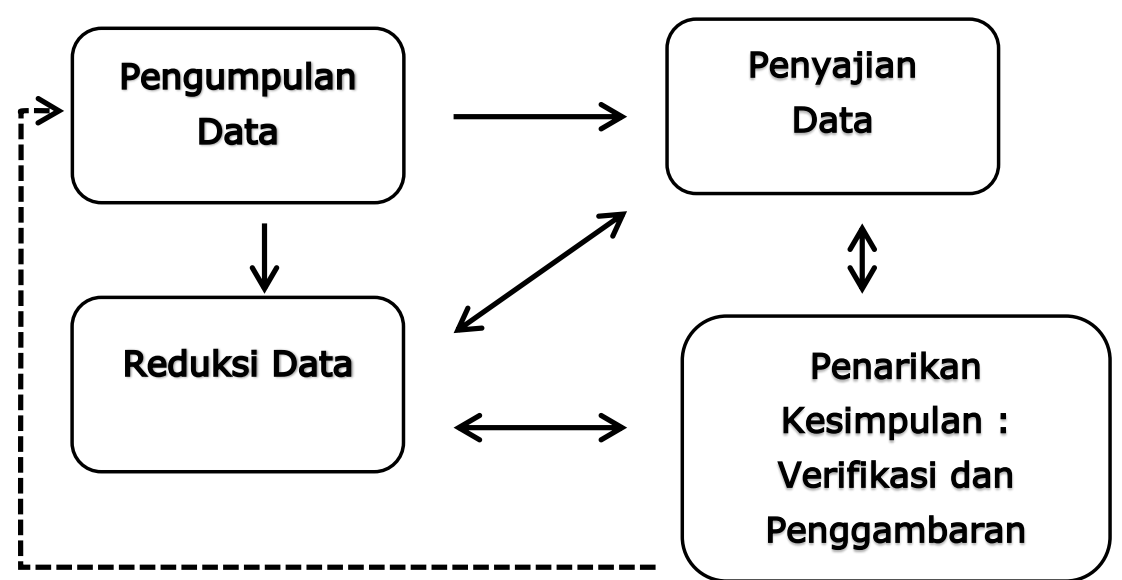

Gambar 1. Ilustrasi analis data interaktif model miles dan huberman

Dari Hal tersebut, penulis menarik Kesimpulan dari jawaban atas lembar observasi yang telah dibagikan kepada koresponden, Kemudian dari jawaban tersebut penulis mengolah data tersebut dalam menentukan respon kumulatif terkait masalah yang dialami koresponden selama menggunakan aplikasi teleconference. Setelah itu, penulis menginpretasikan data numerik dalam bentuk narasi supaya dapat dipahami oleh khalayak.

\section{4) Instrumen Penelitian}

Intrumen yang digunakan dalam penelitian ini adalah lembar observasi. Lembar observasi dalam penelitian ini digunakan untuk menilai atau mengukur kelayakan suatu media pembelajaran. Instrumen ini digunakan untuk mendapatkan data penilaian kelayakan penggunaan multimedia interaktif yang digunakan. Lembar observasi ini diadaptasi dari jurnal internasional yaitu $A$ Method for Evaluating Multimedia Learning Software oleh Stéphane Crozat, Olivier Hû, Philippe. Trigano dan lembar evaluasi media pembelajaran yang dikemukakan oleh Saputro kemudian disesuaikan dengan tujuan peneliti. (Crozat dkk., 1999) Sebelum lembar observasi ini digunakan, dilakukan uji coba dan validasi oleh dosan ahli. Berikut merupakan kisi-kisi lembar observasi:

Tabel 1. Kisi-kisi lembar observasi penilaian media pembelajaran.

\begin{tabular}{|l|l|l|l|l|}
\hline No & Aspek & Indikator & Deskripsi & Jumlah \\
\hline 1 & $\begin{array}{l}\text { Technical } \\
\text { Quality }\end{array}$ & a. Portabilitas & $\begin{array}{l}\text { Multimedia interaktif dapat } \\
\text { dioperasikan pada lingkungan } \\
\text { perangkat keras dan atau perangkat } \\
\text { lunak yang berbeda-beda. }\end{array}$ & 1 \\
\cline { 3 - 6 } & b. Instalasi & $\begin{array}{l}\text { Multimedia interaktif dapat } \\
\text { disinkronkan dengan perangkat keras } \\
\text { tanpa pengistalan aplikasi lain. }\end{array}$ & 1 \\
\cline { 3 - 6 } & $\begin{array}{l}\text { c. Kelancaran } \\
\text { pengoperasian }\end{array}$ & $\begin{array}{l}\text { Multimedia interaktif dapat berjalan } \\
\text { berjalan lancar tanpa ada hang, crash } \\
\text { atau lag. }\end{array}$ & 1 \\
\cline { 3 - 6 } & $\begin{array}{l}\text { d. } \\
\text { Dokumentasi }\end{array}$ & $\begin{array}{l}\text { Dalam multimedia interaktif terdapat } \\
\text { petunjuk penggunaan yang lengkap } \\
\text { dan jelas. }\end{array}$ & 1 \\
\hline 2 & Usability & Konsistensi & $\begin{array}{l}\text { Posisi, bentuk navigasi dan tombol } \\
\text { konsisten serta memiliki warna dan } \\
\text { fungsi yang sama pada setiap screen. }\end{array}$ & 2 \\
\hline
\end{tabular}

A. N. Rasyid,dkk.: Kajian Kritis Penggunaan Aplikasi Tele-Conference Dalam Perkuliahan Online Selama Masa Tanggap Covid-19| 93 


\begin{tabular}{|l|l|l|l|l|}
\hline 3 & \multirow{2}{*}{$\begin{array}{l}\text { Memen } \\
\text { Media Visual }\end{array}$} & a. Teks & $\begin{array}{l}\text { Komposisi teks (ukuran,warna dan } \\
\text { jenis) jelas sehingga mudah dibaca. }\end{array}$ & 1 \\
\cline { 3 - 4 } & $\begin{array}{l}\text { b. Keselarasan } \\
\text { warna teks } \\
\text { dan } \\
\text { background }\end{array}$ & $\begin{array}{l}\text { Keterpaduan antara warna teks dan } \\
\text { background. }\end{array}$ & \\
\cline { 3 - 4 } & $\begin{array}{l}\text { c.Ilustrasi } \\
\text { (gambar, } \\
\text { video animasi) }\end{array}$ & $\begin{array}{l}\text { Kualitas ilustrasi (gambar, video, } \\
\text { animasi) baik dalam segi peletakan, } \\
\text { ukuran dan warna }\end{array}$ & \\
\hline 4 & Pembelajaran & $\begin{array}{l}\text { Pencapaian } \\
\text { Tujuan }\end{array}$ & $\begin{array}{l}\text { Dalam multimedia interaktif memuat } \\
\text { tujuan pembelajaran yang dicapai } \\
\text { mahasiswa }\end{array}$ & 2 \\
\cline { 3 - 5 } & Evaluasi & Evaluasi pada multimedia interaktif & 1 \\
\hline
\end{tabular}

Agar data dalam penelitian kualitatif dapat dipertanggungjawabkan maka penelitian perlu dilakukan uji keabsahan data. Adapun uji keabsahan data yang dapat dilaksanakan.

a. Credibility

Uji credibility (kredibilitas) atau uji kepercayaan terhadap data hasil penelitian yang disajikan oleh peneliti agar hasil penelitian yang dilakukan tidak terjadi miskonsepsi informasi.

I. Perpanjangan Pengamatan

Penelitian ini membutuhkan perpanjangan penelitian agar dapat meningkatkan mutu kredibilitas/kepercayaan data. Dengan perpanjangan penelitian berarti peneliti kembali ke lapangan, kemudian melakukan pengamatan ulang, wawancara ulang dengan sumber data yang komprehensif dan referensi yang lebih up to date.

Perpanjangan pengamatan untuk menguji kredibilitas data penelitian difokuskan pada pengujian terhadap data yang telah diperoleh. Data yang diperoleh setelah dicek kembali ke lapangan benar atau tidak, ada perubahan atau masih tetap. Setelah dicek kembali ke lapangan, lalu data yang telah diperoleh sudah dapat dipertanggungjawabkan, maka perpanjangan pengamatan perlu diakhiri dan dapat dikatakan kredibel.

II. Triangulasi

Untuk menguji kredibilitas data, Wiliam Wiersma mengatakan triangulasi pengujian kredibilitas yaitu proses pengecekan data dari berbagai sumber di berbagai waktu. Dengan demikian terdapat triangulasi sumber, triangulasi teknik pengumpulan data, dan waktu. (Statistik Sugiyono, 2018).

a) Triangulasi Sumber

Untuk menguji kredibilitas data dilakukan dengan cara mengecek data yang telah diperoleh melalui beberapa sumber. Data yang diperoleh dianalisis oleh peneliti sehingga menghasilkan suatu kesimpulan selanjutnya peneliti meminta kesepakatan bersama individu/kelompok yang sedang diteliti (Statistik Sugiyono, 2018).

b) Triangulasi Teknik

Untuk menguji kredibilitas data penelitian ini melakukan dengan cara mengecek data kepada sumber yang sama dengan teknik yang berbeda. Misalnya untuk mengecek data bisa melalui wawancara, observasi, dokumentasi. Bila dengan teknik pengujian kredibilitas data tersebut menghasilkan data yang berbeda, maka peneliti melakukan diskusi lebih lanjut kepada sumber data yang bersangkutan untuk 
memastikan data mana yang dianggap benar (S. Sugiyono, 2007). Dalam hal ini, narasumber yang terlibat dalam wawancara penulis dipastikan telah mengisi lembar observasi.

c) Triangulasi Waktu

Seyogyanya data dikumpulkan dengan teknik wawancara di pagi hari pada saat narasumber masih segar, akan memberikan data lebih valid sehingga lebih kredibel. (S. Sugiyono, 2007) Namun karena situasi yang tidak memungkinkan dilakukan maka penulis dan narasumber melakukan wawancara atas kesepakatan bersama. Selanjutnya pengecekan data dengan wawancara, observasi atau teknik lain dilakukan dalam waktu atau situasi yang berbeda. Bila hasil uji menghasilkan data yang berbeda, maka dilakukan secara berulangulang sehingga sampai ditemukan kepastian datanya.

III. Analisis Kasus Negatif

Melakukan analisis kasus negatif berarti peneliti mencari data yang berbeda atau bahkan bertentangan dengan data yang telah ditemukan. Bila tidak ada lagi data yang berbeda atau bertentangan dengan temuan, berarti masih mendapatkan data-data yang bertentangan dengan data yang ditemukan, maka peneliti mungkin akan mengubah temuannya.

IV. Menggunakan Bahan Referensi

Pengertian referensi adalah bahan pendukung atas pembuktikan data yang bersifat empirik. Dalam laporan penelitian, sebaiknya data-data yang dikemukakan perlu dilengkapi dengan foto-foto atau dokumen autentik, sehingga menjadi lebih dapat dipercaya.

\section{b. Transferability}

Transferability merupakan kemampuan memproses pengecekan data yang diperoleh peneliti kepada narasumber sebagai validitas eksternal. Validitas eksternal berguna untuk menunjukkan derajat ketepatan atau dapat diterapkannya hasil penelitian ke populasi di mana sampel tersebut diambil. (Statistik Sugiyono, 2018) Pertanyaan peneliti berkaitan dengan nilai transfer pada saat ini yang masih dapat diterapkan dalam situasi lain.

Dalam hal ini, peneliti menggunakan nilai transfer yang terdapat di dalam kisi kisi pada jurnal jurnal internasional yaitu $A$ Method for Evaluating Multimedia Learning Software oleh Stéphane Crozat, Olivier Hû, Philippe. tentang Trigano dan lembar evaluasi media pembelajaran yang dikemukakan oleh Saputro. Kisi kisi ini dijadikan pertanyaan yang dapat digunakan dalam konteks berbeda di situasi wawasan wiyata mandala yang lain. Namun disesuaikan dengan tujuan peneliti

\section{c. Dependability}

Pengertian dependability sama halnya dengan reliability pada penelitian kuantitatif. Perbedaannya terletak pada pengujian dependability yang dilakukan dengan cara pengauditan terhadap seluruh proses penelitian. Dalam penelitian ini penulis memulai dengan menentukan masalah, kemudian terjun ke lapangan, memilih sumber data, melaksanakan analisis data, melakukan uji keabsahan data, hingga pada pembuatan laporan hasil penelitian.

\section{d. Confirmability}

Objektivitas pengujian kualitatif disebut juga dengan uji confirmability penelitian. Penelitian bisa dikatakan objektif apabila hasil penelitian telah disepakati oleh lebih banyak orang. Penelitian kualitatif uji confirmability berarti menguji hasil penelitian yang dikaitkan dengan proses yang telah dilakukan. Apabila hasil penelitian merupakan fungsi dari proses penelitian 
yang dilakukan, maka penelitian tersebut telah memenuhi standar confirmability.

\section{HASIL DAN PEMBAHASAN}

Penelitian ini menggunakan pendekatan melalui metode wawancara dan observasi kemudian diperoleh hasil penelitian yang menunjukkan bahwa perkuliahan yang dilakukan oleh mahasiswa Tadris IPA selama masa transmisi virus COVID-19 yaitu penggunaan sistem perkuliahan berbasis online. Wawancara ini dilakukan dengan 2 mahasiswa dan 1 dosen, sedangkan pengisian angket dilakukan oleh 46 koresponden

Menurut mahasiswa 1 sistem perkuliahan online telah dianggap efektif. Kegiatan diskusi jarak jauh berjalan dengan baik dan menyenangkan dengan menggunakan akses internet. Meskipun demikian terdapat suatu kendala selama menggunakan aplikasi Zoom yaitu situasi dan kondisi keadaan wilayah yang jauh dengan jaringan internet. sehingga dapat mengganggu kegiatan mahasiswa karena putusnya koneksi internetnya yang kian melamban, akan tetapi apabila terjadi informasi yang kurang jelas dari dosen akan mengulang penjelasannya hingga mahasiswa memahami materi yang diberikan dosen. Selain menggunakan aplikasi zoom sebagai media penempuh mata kuliah, Mahasiswa Tadris IPA juga menggunakan aplikasi lain seperti WhatsApp, LMS (Learning Management System), Google Classroom dan Edmodo.

\section{A. Hasil Wawancara}

Berikut cuplikan wawancara dengan Mahasiswa A:

Seorang mahasiswa yang menjadi narasumber mengenai penggunaan aplikasi Zoom selama perkuliahan online ini merupakan mahasiswa Tadris IPA. Selama pandemi COVID-19, perkuliahan online dilakukan dengan berbagai cara dan media pembelajaran, salah satunya menggunakan aplikasi teleconference zoom. Mahasiswa A menyatakan "....Dengan adanya aplikasi zoom ini sangat membantu para pelajar khususnya mahasiswa dalam mencapai target belajar mereka. Penggunaan platform ini membuat mahasiswa Tadris IPA dapat melaksanakan diskusi virtual tanpa terbatas oleh ruang dan waktu....".

Dibalik kelebihan aplikasi zoom, terdapat pula kekurangan aplikasi zoom yang diungkapkan mahasiswa A "....terdapat sedikit kendala dalam pemakaian aplikasi tersebut yaitu kekuatan internet yang relatif lamban sehingga mempengaruhi jalannya diskusi..." selain menggunakan aplikasi zoom, mahasiswa A juga menggunakan aplikasi lain, yaitu google classroom dan LMS yang digunakan untuk pengumpulan tugas.

Mahasiswa A mengungkapkan kendala penggunaan zoom "....:Ketika awal penggunaan zoom, saya agak sedikit bingung selama proses penginstalan dan pengoperasian fitur-fitur yang terdapat di aplikasi karena belum terbiasa dengan berbagai fitur-fitur yang tersedia....". mahasiswa A berharap, ketika pembelajaran menggunakan aplikasi zoom Bapak atau ibu dosen mohon lebih bersabar sebab kekuatan signal internet yang dimiliki mahasiswa satu dengan yang lainnya berbeda, serta mohon tidak memberikan tugas yang terlalu berat dan mempersulit mahasiswa.

Berikut cuplikan wawancara dengan Mahasiswa B

Berdasarkan wawancara dengan mahasiswa $B$, diketahui bahwa penggunaan aplikasi zoom selama perkuliahan daring "....penggunaan aplikasi zoom sangat membantu dan efektif, tetapi juga merugikan..." dikatakan membantu oleh mahasiswa B dikarenakan aplikasi zoom dapat melakukan screen layar secara real time layaknya seminar, sehingga bisa membantu dalam hal audionya, dan dikatakan merugikan karena penggunaan aplikasi zoom menghabiskan kuota internet yang banyak dalam sekali penggunaannya, juga terdapat kendala signal "....terkadang sinyal tidak stabil, mungkin bagi yang menggunakan wifi dapat melakukannya dengan lancar....". 
Untuk membantu proses perkuliahan online selama pandemi, Mahasiswa B juga menggunakan media selain zoom "....ketika berdiskusi di dalam kelompok kecil kami biasa menggunakan video call dan discord saja, tetapi untuk kelompok besar yang mana pembelajarannya bersama dosen, kami menggunakan aplikasi teleconference dengan domain VPN milik Kampus seperti zoom...." . mahasiswa B mengungkapkan bahwa kuota internet yang digunakan untuk penggunaan zoom selama perkuliahan online cukup banyak "....dalam seminggu saja saya dapat menghabiskan 10 GB untuk penggunaannya. Mungkin dalam sebulan bisa menghabiskan sekitar 40an GB...."

Mahasiswa B juga menyebutkan terdapat kendala "....kendalanya itu jika jaringan buruk maka perkuliahan jadi tidak nyaman. Selain itu juga terkendala minimnya kuota, sehingga perlu mempersiapkan untuk mengisi kuota data. Dan juga bagi aplikasi zoomnya yang belum premium terdapat batsan waktu dalam pemakainnya...." . mahasiswa B menyampaikan pesan untuk pihak-pihak yang berperan selama perkuliahan daring "....Semangat terus untuk bapak, ibuk dosen, dan juga instansi. Karena telah membantu memberi kami materi perkuliahan dan dapat mengajak kami berpikir. Dan kepada kampus, jagan segan-segan memberikan kuota gratis guna membantu dalam perkuliahan ini, kami mananti...."

Berikut cuplikan wawancara dengan dosen:

Berdasarkan wawancara yang dilakukan terhadap salah satu dosen, yang berpendapat "...saya sebagai dosen sebenarnya merasa bingung kalau mau memberi materi ke mahasiswa. Kalau lewat zoon bener tuh masalah kuota atau jaringan yang sering terjadi menjadi masalah utama. Tapi bisa untuk bimbingan tertulis seperti skripsi dan lain-lain....". dosen tersebut juga menggunakan media selain aplikasi zoom untuk mendukung perkuliahan online yaitu dengan mengoptimalkan mahasiswa membuat video interaktif melalui YouTube yang selanjutnya dikirim melalui google drive.

Kendala yang dialami dosen tersebut adalah keluhan dari mahasiswa tentang jaringan yang Cuma seadanya dan kuota yang minim, sehingga dosen tidak bisa menuntut mahasiswa untuk mencari materi di YouTube atau internet. Maka dari itu, tugas diberikan melalui grup WA secara tertulis tanpa video. Terdapat kendala lain ketika tugas atau perkuliahan dilangsungkan melalui grup WA yaitu mahasiswa yang hadir tidak pernah lengkap, mahasiswa beralasan susah membeli kuota karena tidak mendapatkan uang jajan.

Cara yang digunakan dosen tersebut untuk mengatasi kendala diatas adalah dikembalikan kepada mahasiswa "....Jadi ya akhirnya saya balikin lagi ke mahasiswa. Maunya gimana? dan mereka lebih suka dikasih pertanyaan singkat di WA (WhatsApp) dikerjakan saat itu juga. Intinya sih, kita sebagai pendidik dan calon pendidik yang seharusnya mengerti kondisi masing-masing mahasiswa dan gak bisa dipukul rata semua...."

Hasil wawacara telah yang dilakukan oleh penulis dan narasumber menyatakan, bahwa penggunaan media telekonferensi zoom ini sangat efektif dan membantu para pelajar khususnya mahasiswa dalam mencapai target belajar mereka. Penggunaan platrorm ini membuat mahasiswa Tadris IPA dapat melaksanakan diskusi virtual tanpa terbatas oleh ruang dan waktu. Mereka menjadikan pilihan zoom sebagai alternatif platform tele-Conference yang baik. karena kualitas share on screen yang bagus dari pada aplikasi tele-conference yang lainnya. Namun terdapat sedikit kendala dalam pemakaian aplikasi tersebut yaitu kekuatan internet yang relatif lamban sehingga mempengaruhi jalannya diskusi dan juga aplikasi zoom menggunakan kuota internet yang cukup besar sehingga menjadi kendala bagi para mahasiswa.

\section{B. Hasil Observasi}

Berikut Hasil Observasi menggunakan Google Form:

Data kemampuan Penggunaan Aplikasi Zoom di kalangan Mahasiswa Tadris

IPA IAIN Jember ini dapat dijadikan bahan penelitian oleh penulis. Hasil ini A. N. Rasyid,dkk.: Kajian Kritis Penggunaan Aplikasi Tele-Conference Dalam Perkuliahan Online Selama Masa Tanggap Covid-19| 97 
didapatkan melalui hasil observasi per tanggal 2 Mei 2020 sampai 5 Mei 2020. Data tersebut kemudian dikelompokkan sesuai dengan jawaban terbanyak dari setiap pertanyaan. Persebaran data tersebut dijelaskan pada tabel 2.

Dari pengisian jawaban observasi diperoleh hasil, bahwa sebagian besar mahasiswa Tadris IPA setuju apabila proses perkuliahan online menggunakan aplikasi tele-konferensi Zoom, karena penggunaan zoom lebih efektif membantu pemahaman mahasiswa. Pada dasarnya mahasiswa Tadris IPA yang tergolong orang awam yang relatif bingung ketika hendak mengaplikasikan aplikasi zoom ke dalam perangkat kerasnya. Sehingga apabila ditinjau dari aspek dokumentasi, Mahasiswa Tadris IPA senang ketika mendapatkan bimbingan mengenai penggunaan pemakaian aplikasi zoom oleh dosen. Sedangkan aspek usability, Mahasiswa Tadris IPA sangat paham dengan etika perkuliahan online menggunakan zoom seperti kapan harus menyalakan atau mematikan mikrofon, dan penggunaan aplikasi zoom menghabiskan banyak kuota serta membutuhkan kekuatan sinyal yang sangat baik. Sedangkan, mahasiswa Tadris IPA tidak sedikit yang tinggal di daerah pedesaan atau daerah yang susah sinyal, sehinggal hal tersebut menghambat kelancaran proses perkuliahan online menggunakan aplikasi zoom. Dan apabila ditinjau dari keefektifan durasi perkuliahan, mahasiswa Tadris IPA setuju jika durasi yang digunakan tidak bertele-tele dan lebih efektif membahas topik pokok atau inti.

Zoom Video Communication merupakan Platform yang menyediakan wadah untuk berkomunikasi lewat perangkat videotelefoni. Layanan ini dapat digunakan oleh seluruh kalangan untuk keperluan bekerja jarak jauh, telekonferensi, dan belajar jarak jauh. Platform ini tidak hanya digunakan dalam ranah Pendidikan saja tetapi juga dapat memperlancar Program Pekerjaan Sosial dengan asas Discussions were two-way audiovisual, Zoom untuk digunakan untuk telemedicine kesehatan dalam menangani transmisi virus COVID-19, Zoom untuk berdiskusi dengan basis komunitas, dan lain-lain. (Abdillah, 2020) Bagi civitas academica penggunaan platform ini memudahkan untuk tetap berinteraksi seperti bertatap muka langsung.

Banyak penawaran berupa fungsi khusus di dalam platform ini. Mulai dari kemudahan membagikan file dalam format PDF, hingga memanipulasi background layar kamera, Zoom menawarkan fasilitas termudah untuk orang awam yang ingin bergabung dengan hanya membagikan tautan, Zoom synchronous online formats juga meliputi two-way live broadcast lectures. Fitur tersebut menjadikan zoom dapat disegani oleh para cendikiawan karena dapat membagikan layar slide yang akan dibincangkan sehingga sangat cocok untuk berdiskusi secara live. Zoom menjadi kursus online terpopuler karena dapat menghemat waktu perjalanan, biaya bahan bakar, dan dapat mengurangi dampak terhadap lingkungan. Zoom menawarkan biaya finansial yang relatif rendah dalam penggunaan webinar yang baik (Hidayatullah dkk., 2020).

Terlepas dengan banyaknya fitur bukan berarti aplikasi ini terlepas dari keresahan, justru platform ini memiliki banyak keluhan tentang kelancaran perkuliahan yaitu pemborosan dalam kuota terpakai selama tele-lecturer selama penggunaan platform ini. Tele-lecurer atau perkuliahan jarak jauh masih menjadi Polemik dikalangan civitas academica, dikarenakan perkuliahan berbasis online ini masih dianggap tidak optimal daripada perkuliahan secara konvensional, terutama dalam lingkungan Mahasiswa Tadris IPA IAIN Jember. Hal tersebut disebabkan karena dalam mempelajari ilmu alam orang harus berpikir ilmiah agar ia mampu mampu menggunakan metode ilmiah untuk digunakan serta mampu menggunakan konsep-konsep ilmu alam secara akurat. Dengan mengetahui masalah tersebut, maka seharusnya calon Pendidik IPA, Mahasiswa tadris IPA seyogyanya memahami dan mengembangkan berbagai metode pembelajaran yang baik untuk proses belajar mengajar.

Pendidik dan mahasiswa hendaknya dapat menyusun program pengajaran supaya membangkitkan motivasi belajar mahasiswa yang lainnya sehingga mahasiswa terlibat aktif dalam proses perkuliahan. Media perkuliahan seharunya diaplikasikan berupa media dalam pengembangan model perkuliahan yang 
membuka wawasan kepada mahasiswa untuk membangun pemahamannya sendiri sehingga mahasiswa lebih ringan untuk memahami konsep-konsep yang diajarkan dan menginterpretasikan ide-idenya dalam bentuk lisan maupun tulisan.

\section{Hasil Focus Group Discussion (FGD)}

Penelitian kualitatif ini juga menggunakan metode pengumpulan data dengan teknik Focus Group Discussion (FGD). FGD atau diskusi kelompok terfokus adalah suatu kegiatan diskusi kelompok yang diadakan untuk kepentingan khusus guna mendiskusikan suatu masalah melalui asumsi-asumsi yang tengah beredar (brain storming) (Paramita \& Kristiana, 2013). Berdasarkan penelitian yang telah dilakukan peneliti tentang penggunaan aplikasi Zoom pada Mahasiswa Tadris IPA IAIN Jember. Maka penulis akan merincikan hasil FGD yang telah disepakati bersama, antara lain:

1. Harapan Penggunaan Zoom bagi Mahasiswa

Peneliti berharap dengan adanya aplikasi Zoom dapat membantu dan memperlancar proses pembelajaran serta perkuliahan. Selain itu, mahasiswa juga berharap pada setiap dosen pengampu mata kuliah yang menggunakan aplikasi Zoom dapat memahami kondisi perbedaan kekuatan sinyal antar mahasiswa

2. Faktor yang Mempengaruhi Mahasiswa dalam Pelaksanaan Telekonferensi Zoom Mahasiswa sepakat mengungkapkan faktor utama yang mempengaruhi pembelajaran menggunakan Teleconference Zoom adalah minimnya jangkauan sinyal pada daerah mereka. Selain itu, aplikasi Zoom menghabiskan kuota internet yang banyak dalam penggunaannya.

3. Mekanisme Pelaksanaan Zoom

Mekanisme pembelajaran dalam bentuk dua pendekatan sekaligus (Blender Method) seperti Teleconference Zoom ini. Blended Method adalah mekanisme pembelajaran daring (dalam jaringan) sekaligus dapat bertatap muka melalui video teleconference dengan dosen pengampu mata kuliah (Graham, 2006)

4. Syarat Pelaksanaan Telekonferensi Zoom

a. Perangkat keras anda memiliki Kamera. baik yang sudah tertanam di perangkat pintar atau webcam terpisah, dan Perangkat tersebut mempunyai kamera yang cukup baikuntuk mengakses Zoom.

b. Perangkat keras anda memiliki Mikrofon atau mic. Sama seperti kamera, biasanya mic juga sudah tertanam di perangkat pintar. pengguna bisa mengetes suara melalui pengaturan audio di aplikasi. Jika output dan input suara bermasalah, sebaiknya pengguna menggunakan mic atau headset terpisah.

c. Perangkat keras anda terdapat Koneksi internet. untuk menghubungkan pengguna dengan pengguna lain melalui video call, maka pengguna memerlukan koneksi internet yang cepat dan stabil.

d. Perangkat keras anda terinstal Aplikasi Zoom, sebaiknya anda menginstal aplikasi Zoom daripada mengaksesnya melalui browser.

5. Pelaksanaan Telekonferensi Zoom

Agar dapat menggunakan Zoom, maka pengguna hanya perlu mendaftarkan diri secara gratis, baik melalui aplikasi di ponsel atau website, berikut pelaksanaannya:

Apabila diakses melalui Website:

a. Kunjungi zoom.us, lalu klik tombol Sign Up

b. Isi kolom email dengan email aktif anda, lalu cek email dari Zoom di kotak masuk anda.

A. N. Rasyid,dkk.: Kajian Kritis Penggunaan Aplikasi Tele-Conference Dalam Perkuliahan Online Selama Masa Tanggap Covid-19| 99 
c. Klik "Activate Account" hingga anda kembali diarahkan ke browser untuk membuat password baru. Sekarang anda telah aktif.

d. Jika anda telah mempunyai akun, maka anda dapat memilih Sign In, lalu memasukkan email dan password yang anda gunakan untuk mendaftar Zoom Meeting.

Apabila diakses melalui ponsel:

a. Buka aplikasi Zoom, lalu klik Sign Up.

b. Masukkan alamat email, nama depan, dan nama belakang yang ingin anda tampilkan bagi pengguna lain. Jangan lupa untuk mencentang persetujuan Terms of Service. Setelah itu, klik Sign Up.

c. Zoom akan mengirimkan email ke alamat email yang anda gunakan.

d. Klik "Activate Account" di email yang masuk dari Zoom.

e. Lalu anda akan diminta untuk menentukan password untuk akun Zoom milik anda. Selesai.

f. Jika sudah punya akun, anda bisa memilih Sign In, Ialu memasukkan email dan password yang anda gunakan untuk mendaftar Zoom Meeting.

Tutorial Penggunaan Zoom Meeting

a. Buka aplikasi Zoom, lalu klik "Start" seperti pada gambar

b. Klik "Invite Others". Anda bisa mengundang peserta melalui email atau menyalin link yang tertera.

c. Tunggu hingga semua peserta masuk ke ruang meeting. Jika diperlukan, kunci ruang meeting dengan memberi tanda centang pada pilihan "Lock Meeting" di menu Security seperti pada gambar.

d. Jika perlu, anda juga bisa merekam meeting yang sedang berlangsung dengan mengklik menu Record seperti pada gambar. Nantinya, data yang terekam akan diubah menjadi format .mp4.

e. Mengingat anda adalah Host, jika meeting telah berakhir, anda bisa memilih untuk mengakhiri meeting untuk semua atau meninggalkan meeting dengan mengklik "End Meeting" di sebelah kanan bawah. Lalu pilih sesuai kebutuhan anda.

6. Hasil Pengembangan Model

Hasil pengembangan model masih bersifat hipotetik, karena masih belum teruji secara empiris. Model Hipotetik merupakan Bagian yang berisi desain model pengembangan pembelajaran. Desain ini umumnya dikembangkan berdasarkan teori yang telah tersedia dan disesuaikan dengan kondisi penelitian dan pengembangan di lapangan. (Sulistiyono, 2020) Dalam hal ini peneliti tidak menjabarkan secara detail karena peneliti tidak berhak berbuat organisatoris pada kelas mata kuliah yang terkait.

\section{KESIMPULAN}

Zoom Video Conference menjadi aplikasi yang banyak diminati oleh semua kalangan terutama civitas academica. Sebagian besar roda pendidikan pada era pandemi COVID-19 ini menjadikan Zoom sebagai platform yang efektif untuk perkuliahan jarak jauh. Zoom ini juga menjadi wadah untuk mahasiswa jurusan Pendidikan IPA termasuk Prodi Tadris IPA IAIN Jember. Menurut hasil survey yang dilakukan oleh penulis, bahwa mahasiswa sepakat apabila proses perkuliahan online menggunakan aplikasi Telekonferensi Zoom, karena penggunaan Zoom dapat mempelancar dan mempermudah jalannya diskusi sehingga mahasiswa tetap dapat melakukan pembelajaran walaupun dalam jarak jauh. Namun, tidak menutup kemungkinan beberapa mahasiswa mengalami kendala dalam penggunaanya. Kendala tersebut yaitu kuota akses internet akan banyak tersedot selama menggunakan Zoom. Hal itu dapat diatasi dengan memaksimalkan waktu diskusi yang telah tersedia. 


\section{DAFTAR PUSTAKA}

Abdillah, L. A. (2020). Online Learning Menggunakan Zoom Teleconference.

Ali, M. (2009). Pengembangan media pembelajaran interaktif mata kuliah medan elektromagnetik. Jurnal Edukasi Elektro, 5(1).

AR, M. F. (2018). Sejarah Media: Transformasi, Pemanfaatan, dan Tantangan. Universitas Brawijaya Press.

Arsyad, A. (2011). Media pembelajaran. Jakarta: PT Raja Grafindo Persada.

Crozat, S., Hû, O., \& Trigano, P. (1999). A method for evaluating multimedia learning software. Proceedings IEEE International Conference on Multimedia Computing and Systems, 1, 714-719.

Fitria, F., Hilmanto, D., Husin, F., Mose, J. C., Sekarwana, N., \& Nurihsan, J. (2016). Penerapan Telekonferensi Video pada Pembelajaran Praktik Klinik terhadap Peningkatan Soft Skills Mahasiswa D III Kebidanan. Jurnal Pendidikan dan Pelayanan Kebidanan Indonesia, 3(1), 36-43.

Graham, C. R. (2006). Blended learning systems. The handbook of blended learning: Global perspectives, local designs, 3-21.

Gunawan, I. (2013). Metode penelitian kualitatif. Jakarta: Bumi Aksara, 143.

Hidayatullah, S., Khouroh, U., Windhyastiti, I., Patalo, R. G., \& Waris, A. (2020). Implementasi Model Kesuksesan Sistem Informasi DeLone And McLean Terhadap Sistem Pembelajaran Berbasis Aplikasi Zoom Di Saat Pandemi Covid-19. Jurnal Teknologi dan Manajemen Informatika, 6(1), 45-53.

Karolcík, Š., Cipková, E., Hrušecký, R., \& Veselský, M. (2015). The comprehensive evaluation of electronic learning tools and educational software (CEELTES). Informatics in Education, 14(2), 243-264.

Kusuma, J. W., \& Hamidah, H. (2020). Perbandingan Hasil Belajar Matematika dengan Penggunaan Platform Whatsapp Group dan Webinar Zoom Dalam Pembelajaran Jarak Jauh Pada Masa Pandemik Covid 19. JIPMat, 5(1).

MARDININGRUM, K. D. (2020). Kompetensi Pedagogik Guru Dalam Pembuatan Media Pembelajaran untuk Meningkatkan Prestasi Belajar Siswa di MI Nurul Falah Sawo Kutorejo Mojokerto.

Miles, M. B., \& Huberman, A. M. (1994). Qualitative data analysis: An expanded sourcebook. sage.

Mona, N. (2020). Konsep Isolasi Dalam Jaringan Sosial Untuk Meminimalisasi Efek Contagious (Kasus Penyebaran Virus Corona Di Indonesia). Jurnal Sosial Humaniora Terapan, 2(2).

Morse, J. M. (2015). Critical analysis of strategies for determining rigor in qualitative inquiry. Qualitative health research, 25(9), 1212-1222.

Paramita, A., \& Kristiana, L. (2013). Teknik Focus Group Discussion Dalam Penelitian Kualitatif. Buletin Penelitian Sistem Kesehatan, 16(2), 20840.

Rusdiantoro, A. (2020). Identifikasi Kesalahan Peserta Didik dalam Menyelesaikan Soal Induksi Matematika dengan Teknik Analisis Miles Dan Hubberman. Jurnal Inovasi Pembelajaran Karakter, 5(2).

Sugiyono, S. (2007). Metode Penelitian Kualitatif Kuantitatif dan R \& D. Bandung Alf.

Sugiyono, Statistik. (2018). Metode Penelitian Kualitatif untuk Penelitian yang Bersifat: Eksploratif, Enterpretif, Interaktif dan Konstruktif. Bandung: CV. Alfabeta.

A. N. Rasyid,dkk.: Kajian Kritis Penggunaan Aplikasi Tele-Conference Dalam Perkuliahan Online Selama Masa Tanggap Covid-19| 101 
Sulistiyono, J. (2020). Model Manajemen Pelatihan Tik "Dfh (Daring From Home)" Guru SMA Negeri di Kota Semarang. Jurnal Penelitian Tindakan Kelas, 20(2). 